\title{
Luminescence of Nucleosides, Nucleotides, and DNA at $77^{\circ} \mathrm{K}($ Abstract_要旨)
}

$\operatorname{AUTHOR}(S):$

Imakubo, Keiichi

CITATION:

Imakubo, Keiichi. Luminescence of Nucleosides, Nucleotides, and DNA at $77^{\circ} \mathrm{K}$. 京都大学, 1968, 理学博士

ISSUE DATE:

1968-03-23

URL:

http://hdl.handle.net/2433/212831

RIGHT: 


\section{【28 】}

氏 名

学位 $の$ 種 類 学 位. 記 番号 学位授与の日付 学位授与の要件 吥究科・尃攻 学位論文題目
今久 久保慶 一

理学 博士

理 博 第 130 号

昭和 43 年 3 月 23 日

学位規則第 5 条第 1 項該当

理学研究科原子核理学専攻

Luminescence of Nucleosides, Nucleotides, and DNA at $77^{\circ} \mathrm{K}$

(77K K に抢けるヌクレオサイズ，又クレオタイズ，及びデオキシリ ボ核酸の発光）

論文調查委員教主授查四手井綱彦 教授武藤二 郎教授寺本英

\section{論文内容の要旨}

主論文は DNA 分子の励起状態上分子内に标けるエネルギー移動機構を明らかにするとをを目的とし たものである。まず，核酸を構成している 5 種類の塩基の誘馟体であるヌクレオシドとヌクレオチドの励 起状態を明らかにするため, 紫外線励起による蛍光と燐光とを調べた。乙の実験で得られた資料を基とし て, DNA 分子の励起一重項状態 $\left(\mathrm{S}_{1} *\right)$ と三重項状態 $\left(\mathrm{T}_{1}\right)$ とが，どの塩基からの寄与によるものであ るかを検討した。

実験条件は, $10^{-4} \sim 10^{-3} \mathrm{~mol} / \mathrm{l}$ の試料を，1：1容舅比の燐酸バッファーとエチレングリコールの混合溶 媒に溶解させ， $77^{\circ} \mathrm{K}$ に凍結させた状態で， $265 m \mu$ の紫外線で励起した。溶液の $\mathrm{pH}$ は中性である。塩基 誘導体についての燐光測定の結果は次のように要約できる。

(1) プリン及びピリミジン誘導体はともに $T_{1}$ 一状態からの燐光が観測されたが，その平均寿命は前者 で約1.2〜2.5秒であり，後者では約 0.5 秒であった。燐光強度は前者の方が後者より $1 \sim 2$ 桁も強い。プ リン誘導体の燐光は従来報告されていたものとよく一致するが，ピリジン誘導体の中性溶液に怙ける燐光 は従来観測されていない。(2)燐光のスペクトルから 5 種類の塩基の $\mathrm{T}_{1}$ 一状態のエネルギーを求めると, シトシン $(\mathrm{C})$, グアニン $(\mathrm{G})$, アデニン $(\mathrm{A})$, ウラシル $(\mathrm{U})$, チミン $(\mathrm{T})$ の順になり, チミンの $\mathrm{T}_{1}$ が最もひくい。

DNA 分子の燐光強度はプリン誘導体の燐光強度に比べて弱く,そのスペクトルの形は TMP（チミジ ン・モノホスフェート）のpH7のスペクトルと比較的よく類似し, 従来考えられていたアルカリ性溶液で のT一塩基のスペクトルとは必ずし屯一致しない。更に DNA 分子の燐光平均寿命の波長依存性を調べ ると，TMP の燐光ピーク付近の波長 $(445 m \mu)$ では大部分がT一塩基からの寄与によるものと見るとと ができるが，プリン誘等体の燐光ピークの波長 $(405 m \mu)$ で T一塩基からの笴与よりも，A一塩基からの 寄与が上まわると見られる。TとAの燐光の量子収率が $1: 10$ 以下であるととを考慮すると, DNA 分子 の $\mathrm{T}_{1}$ 状態仙 $95 \%$ 以上が $\mathrm{T}$ 一塩基からの寄与であり, 残りが $\mathrm{A}$ 一塩基からのものであると推論できる。 
次に熱変性によって一本鎖にほよ゙いた denatured DNA の燐光スペクトルが，二本鎖の native DNA のスペクトルと略一致するととを見出している。てれら燐光に関する観測結果を総合すると，Rahn 等に よって提唱されている次の仮説は支持できないと結論する。「DNA 分子の $\mathrm{T}_{1}$ 状態は， $\mathrm{pH}>10$ の溶液中 で観測されるT一誘導体のそれとよく一致する。したがって，ての分子内では，水素結合を介して陽子が $\mathrm{T} \rightarrow \mathrm{A}$ と移動するととによって励起エネルギーの移動が行なわれる。」

蛍光の観測結果からは，プリン誘導体とピリミジン誘導体との間に著しい相違点は見出されていない。

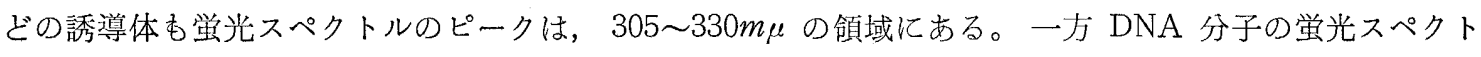
ルは $360 m \mu$ 付近にピークをもち，分子を構成している塩基の誘導体のいずれの蛍光スペクトルとも一致 せず，長波長側にずれている。また， denatured DNA の蛍光スペクトルは， native DNA のそれと殆 んど差異が見られない。てれらの結果を次のように解釈している。「DNA 分子内では，それを構成する 塩基はその分子面が互に平行であり，しあかなり近接して重なり合いの状態にあるととが知られている。 したがって，DNA 分子の同一鎖の隣接している塩基間に $\pi$ 電子間相互作用が存在し，ある* S $_{1}$ 状態での 塩基とそれに隣接する基底状態の塩基とが結合し，いわゆる excited dimer を形成する」。このような解 釈は，二個の塩基が化学結合しているディヌクレオチドの蛍光スペクトルが，それを構成する塩基の蛍光 スペクトルより長波長側にずれているととによっても支持される（参考論文4）。ディヌクレオチドの塩 基分子面の重なり合いは，施光分散の測定から知られている。

以上の観測結果と推論とより，DNA 分子内に扔ける紫外線による励起エネルギーは，その二本鎖間の 水素結合を経由して移動するのではなく，同一鎖の塩基間をチミン塩基に向かって大半が移動すると結論 している。

参考論文 1 は，アントラセン・テトラセン混晶の放射線熱発光に打ける濃度効果を調べたむのである。 参考論文 2 は， ヌクレオチドおよび DNA の燐蛍光に関する研劣の予報で，主論文の前提となるもので ある。参考論文 3 抽び 4 では，いずれも，ディヌクレオチドの燐光並びに蛍光を取り扱ったもので，主 論文と密接な関係をもつ研究である。

\section{論 交軋查の 結果の要旨}

主論文は DNA 分子の紫外線による励起状態と，分子内での励起エネルギーの移動機構とを明らかに するととを目的としている。この問題は量子生物学の基本的資料を提出するあのであり，また最近の問題 である紫外線の致死効果，とくに，ピリミジンダイマーの生成とあ関連した重要な課題である。

申請者は，まず，DNA 分子を構成している塩基の誘導体であるヌクレオシドとヌクレオチドの燐光 を，そのスペクトルと平均寿命とについて系統的に調べた。その結果ピリミジン誘導体の燐光を中性溶液 ではじめて見出した。従来の報告によると，乙の種誘導体の燐光は，強アルカリ溶液中以外では観測され ず，ESR 測定であ三重項状態の存在は見られていなかった。この新しい観測によって，DNAの燐光状態 に関する見方は，改めねばならないことになった。

DNA の燐光スペクトルを, 塩基誘導体の燐光スペクトル（と比べると，上に述べた中性溶液で観测さ れたチミン誘導体のスペクトル）が最もよく類似するととが確認された。また燐光寿命の波長依存性の測 
定から，DNA 分子の紫外線照射によって誘起される三重項状態の $95 \%$ 以上はチミン塩基からの寄与であ ると結論している。

さらに，熱变性によってつくった denatured DNA の燐光スペクトルと， native DNA の燐光スペク トルとを比べると，そのスペクトルの形および寿命等について，殆んど差異が見られない。上述の DNA 分子の三重項について得た見解と合考えると，従来 Rahn 達によって提唱されていた，「DNA 分子内 では，水素結合を介して一個の陽子が $\mathrm{T}$ （チミン）（A（アデニン）と移動し，その三重項状態は強アル カリ性溶液でのT一誘導体のそれと一致する」，という仮説は成立しないと指摘している。

DNA 分子の蛍光スペクトルの観測汃ら得られた主要な結果は, 各塩基誘導体の蛍光スペクトルに比べ て著しく長波長側にずれているととである。とのととより，DNA 分子の同一鎖の中で隣接している塩基 間に， $\pi$ 電子相互作用があり， excited dimer を作るものとしている。との結論は，DNA 分子内で塩基 はその分子面が互に平行で，かなり近接して重なり合った構造をあってとより見て，妥当な結論である。 以上の結果に基づいて，DNA 分子内に扔けるエネルギー移動について，次のような興味ある考え方を 提唱している。「DNA 分子内に括ける励起エネルギー移動は，二本鎖間の水素結合を経由するのではな く，同一鎖の塩基閒を移動する。以上のように，この論文は DNA 分子内におけるエネルギー移動の機 構について，一つの解答を与え，また DNA 分子並びに塩基誘導体のエネルギ一準位に新しい知見を加 えたもので，放射線生物物理学並びに量子生物学の発展に寄与するとてろが少なくない。 よって，本論文は理学博士の学位論文として価值があるものと認める。 